\title{
Cushing's dogged struggle against death: the astonishing case of a patient under cardiac arrest surviving craniopharyngioma surgery
}

\author{
Ruth Prieto, MD, PhD, ${ }^{1}$ and José María Pascual, MD, $\mathrm{PhD}^{2}$ \\ ${ }^{1}$ Department of Neurosurgery, Puerta de Hierro University Hospital; and 2Department of Neurosurgery, La Princesa University \\ Hospital, Madrid, Spain
}

\begin{abstract}
The decisive role Dr. Harvey Cushing (1869-1939) played in medicine goes far beyond the development of neurosurgery. His scientific devotion and commitment to patient care made him an ethical model of strict professionalism. This paper seeks to analyze the decisions Cushing made with the challenging case of HW, an adolescent boy with a craniopharyngioma (CP) involving the third ventricle. Cushing's earlier failure to successfully remove two similar lesions alerted him to the proximity of HW's tumor and the hypothalamus. Consequently, he decided to use the chiasm-splitting technique for the first time, with the aim of dissecting the CP-hypothalamus boundaries under direct view. Unexpectedly, HW suffered cardiac arrest during the surgery, but Cushing did not give up. He continued with the operation while his assistants performed resuscitation maneuvers. Such determined and courageous action allowed Cushing to succeed in an apparently hopeless case. Cushing's unwavering willingness to save patients' lives, even under extreme circumstances, was a fundamental trait defining his identity as a neurosurgeon. Analyzing the way Cushing dealt with HW's case provides valuable lessons for neurosurgeons today, particularly the importance of assuming proactive attitudes and, in certain cases, making painstaking efforts to overcome daunting situations to save a life.
\end{abstract}

https://thejns.org/doi/abs/10.3171/2019.11.JNS192487

KEYWORDS Harvey Cushing; Cushing's legacy; cardiac arrest; craniopharyngioma; history; pituitary surgery; ethics

\begin{abstract}
No one has the right to undertake the care of any patient unless he is willing to give that patient all of the time and thought which is necessary, and of which he is capable.
\end{abstract}

$$
\text { -Harvey Cushing }
$$

In Bailey P: Up From Little Egypt.

$$
\text { Chicago: Buckskin Press, 1969, p. } 210^{4}
$$

Harvey Cushing (1869-1939) should be recognized not only as the American father of neurosurgery but also as a great scholar of medicine. He was an academic surgeon, equally committed to clinical work, writing, teaching, and experimental research (Fig. 1). 2,6,11,15,19,21,27,41 Cushing pursued the scientific ideal of a dedicated physician with the utmost intensity, devoting all possible time and energy to find the best management strategy in each individual case. ${ }^{13}$ In addition to conducting all surgical procedures for every one of his patients, from the first incision to the last stitch, Cushing himself controlled everything that had to do with their perioperative care with great patience and gentleness. ${ }^{15,23} \mathrm{He}$ fought tirelessly against the concept of the surgeon being merely an operator led by neurologists and was directly involved in every phase of treatment, agonizing over his patients to maximize their chances for survival. ${ }^{411,12,15,17,33,38}$ The key to Cushing's professional success was his intellectual independence and deep understanding of the morbid factors underlying neurological diseases. ${ }^{1,18,25}$

Even as a young medical student, Cushing learned and always bore in mind that life and death were so often in a doctor's hands. ${ }^{27}$ Disheartening experiences were the major fuel for his insatiable curiosity, which led to groundbreaking advances in scientific knowledge and operative treatments. Specifically, craniopharyngiomas (CPs) represented the greatest surgical challenge he faced throughout his career. ${ }^{10,29} \mathrm{He}$ treated a total of $124 \mathrm{CPs}$, but one particular case drew our attention when we examined the Cushing Brain Tumor Registry (BTR) files housed at the Manuscripts and Archives Department at Sterling Memorial Library at Yale University, in New Haven, Connecticut. ${ }^{14,29,37}$ It was the record of surgical case number 25886 , which we will refer to using the patient's initials (HW). ${ }^{14}$

ABBREVIATIONS BTR = Brain Tumor Registry; CP = craniopharyngioma; TSA = transsphenoidal approach .

SUBMITTED September 10, 2019. ACCEPTED November 18, 2019.

INCLUDE WHEN CITING Published online January 17, 2020; DOI: 10.3171/2019.11.JNS192487. 


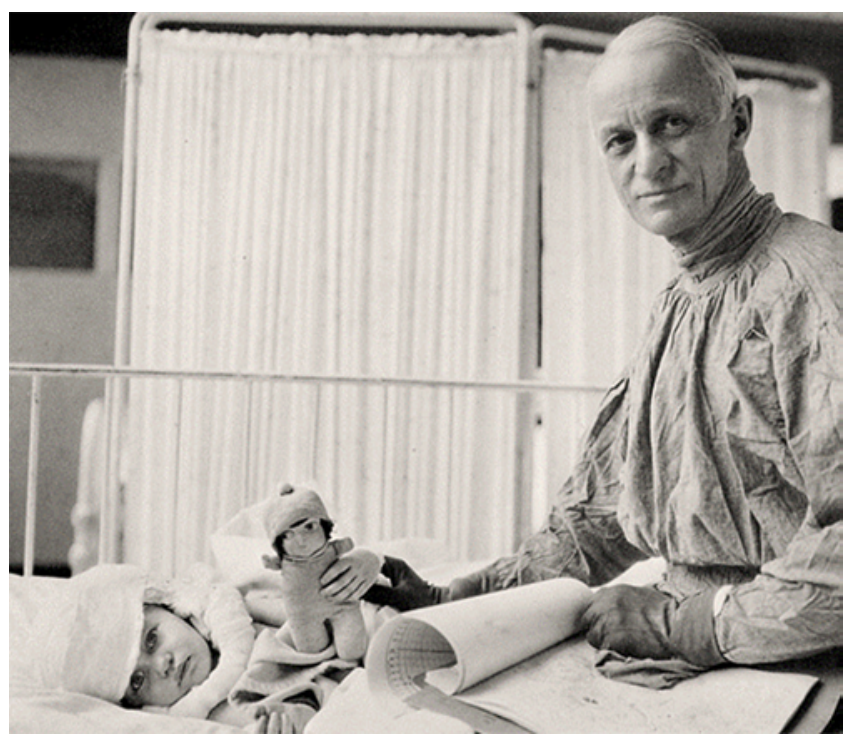

FIG. 1. Dr. Harvey Cushing, a devoted academic surgeon: Cushing photographed with a young patient in 1928 at the Peter Bent Brigham Hospital, illustrating his personalized patient care. The photographed patient is a young girl after one of the seven operations that she would undergo for a cerebellar tumor. Reprinted with the kind permission of Yale University, Harvey Cushing/John Hay Whitney Medical Library (identifier: $\mathrm{HC}$ _and_pediatric_patient.dc). Figure is available in color online only.

The patient was a 17-year-old boy who survived in good clinical condition, even after suffering cardiac arrest during surgery (Figs. 2-4). Cushing removed HW's CP extending from the sella to the third ventricle, while his assistants performed resuscitation maneuvers. Additionally, in HW, Cushing first used the technique of chiasm splitting to avoid blind surgical manipulations of the vital hypothalamic tissue surrounding third-ventricle CPs. In this article we analyze the decisions Cushing made in this desperate situation, illustrating his level of commitment to each patient and his resolve to do the best he possibly could.

\section{Cushing's Rigorous Commitment to Patients: Tracing Back Its Origins}

Cushing considered medicine such a serious responsibility that no one should undertake it unless they were willing to give the best of one's self with total dedication. ${ }^{6,9,13,15}$ This rigorous and demanding work ethic was mainly forged during his formative years in Baltimore, where he was inspired by two of the greatest and most ethical figures of modern medicine: the clinician Sir William Osler and the surgeon William Halsted..$^{15,19,40}$ Osler taught Cushing the importance of patient care, careful observation, studying, and writing. ${ }^{2,16}$ From Halsted, he learned meticulous surgical methods, in particular the use of precise hemostasis and gentle tissue handling, in addition to a highly disciplined lifestyle. . $^{6} 6$

Cushing's enthusiasm, tenacity, and dogged perseverance were the basis for his never giving up. ${ }^{2,39} \mathrm{He}$ was a bad loser, constantly demanding perfection of himself in every single operation. ${ }^{8,15,41}$ His obsessive zeal for patient safety was such that he always operated in his own surgical room surrounded by his exclusively chosen team in an attempt to control every detail. ${ }^{4,13,19}$ Cushing's sense of responsibility toward his patients also caused him great suffering, and every patient he lost he took as a personal failure. ${ }^{4,12}$ The capacity he had for sustained work was also remarkable. ${ }^{3,7,15,17,21}$ Concerning surgery, he was not merely content to excel during the operation. The first thing he immediately and unfailingly did after every procedure was to write a meticulous description that included sketches of the fundamental surgical phases. ${ }^{43}$ Cushing's painstaking record of the clinical histories, surgical procedures, and pathological studies of his patients was motivated not only
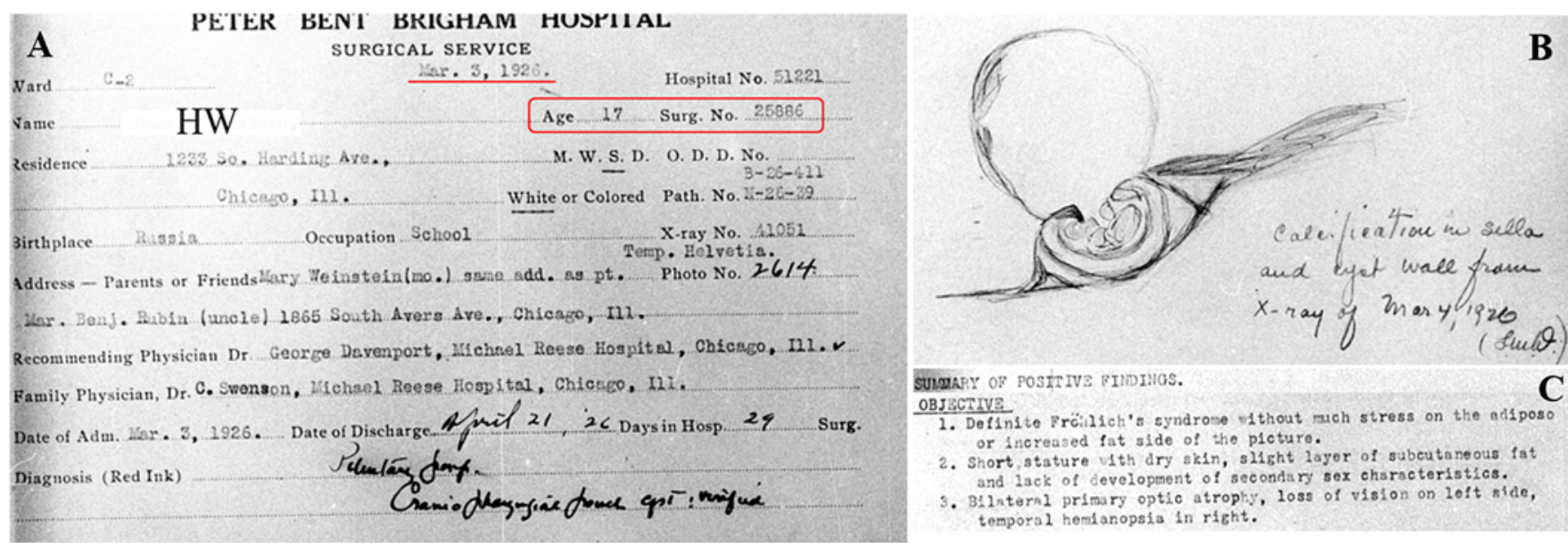

SULARPY OF POSITIVE PIIDIIGS.

OBJBCTIVE or Increased fat side of the ploturo.

2. Short atature Wth dry skin, slight layer of subeutaneous lat and lack of devolopment of secondary sex characteristios. Bilsterni primary optic atroply, loss of vision on left side, tempors l hemianopsia in right.

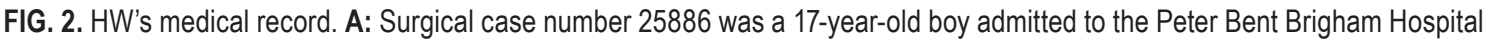
under Cushing's care in March 1926. B: Sketch of his lateral skull radiograph demonstrating sellar calcifications and a curvilinear shadow related to calcification of the cyst wall that largely occupies the third ventricle. C: Summary of his presenting symptoms. Courtesy of the Manuscript and Archives Department of the Sterling Memorial Library, Yale University. Public domain. Figure is available in color online only. 

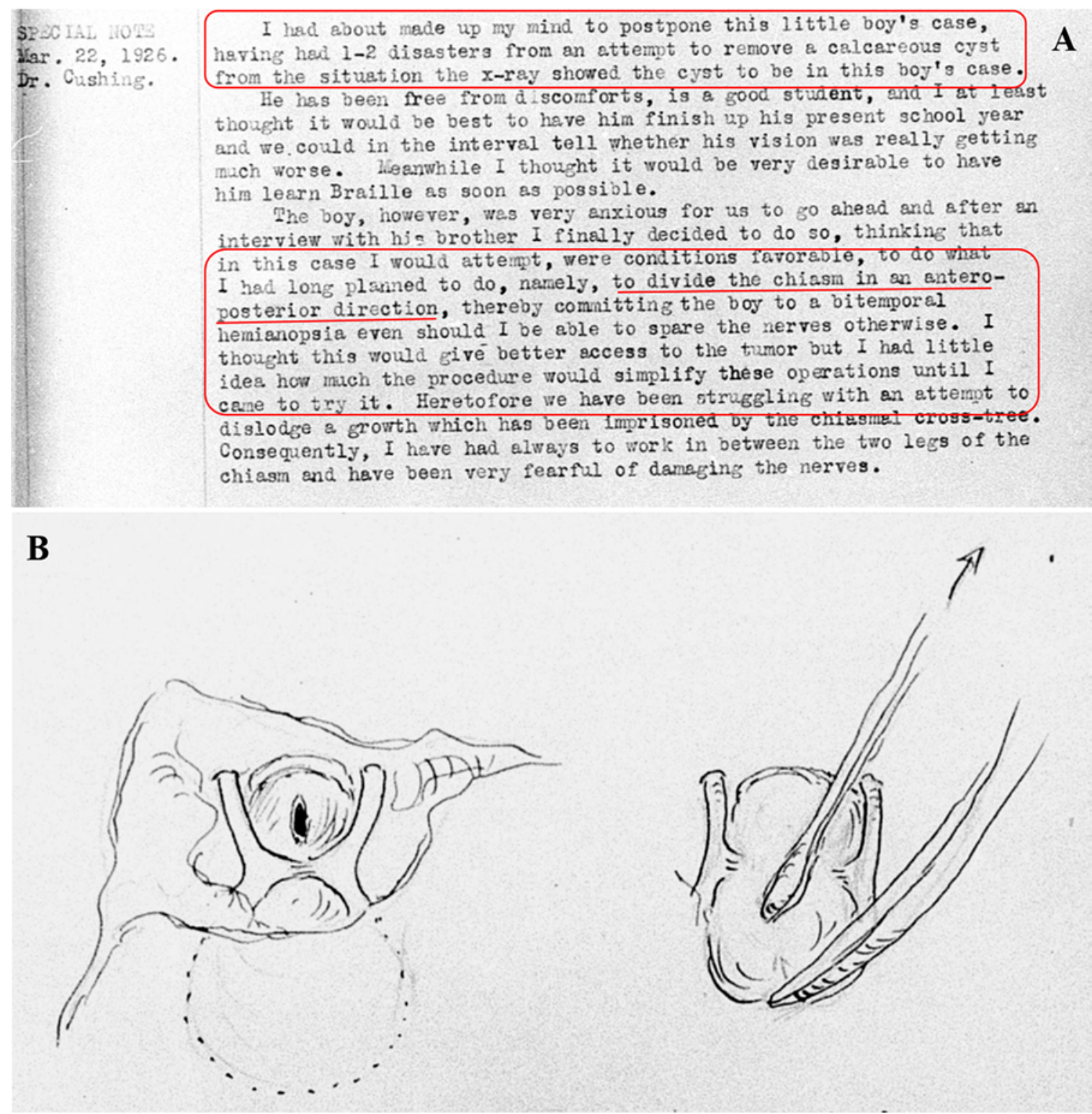

FIG. 3. Cushing's reflections on the surgical difficulty of HW's case and drawing of the first-ever use of the chiasm-splitting strategy. A: Special note written by Cushing on March 22, 1926. The upper red frame highlights the section in which Cushing expressed his concern about HW as his clinical presentation was similar to 1-2 previous CP cases with a fatal ending. The lower red frame indicates Cushing's reflection about the possibility of splitting the optic chiasm to adequately reach HW's tumor. B: Cushing's sketch of the surgical view following a subfrontal approach (left) and chiasm-splitting technique (right). Courtesy of the Manuscript and Archives Department of the Sterling Memorial Library, Yale University. Public domain. Figure is available in color online only.

by patient care, but also by his desire to advance medical knowledge. ${ }^{12}$ Cushing's BTR is full of his own reflections about the decisions taken with every patient and the lessons that could be applied to similar cases in the future.,14

\section{Battle Against Cardiorespiratory Arrest in Neurosurgical Patients: Cushing's Courageous Response Rooted in Tragic Incidents From Early in His Career}

Cushing treated HW in March 1926, but it is first nec- essary to look back to when he was a second-year medical student at Harvard Medical School in order to understand his reaction during HW's surgery. On January 10, 1893, Cushing faced an incident that forever established an awareness that the life and death of the patients he treated would largely depend on his knowledge and technical skills. He had been asked to administer ether to a woman who was to undergo an operation for a strangulated hernia. ${ }^{39}$ Two unfortunate factors coincided in this case, i.e., lack of knowledge and hurry. At that time, there was no formal training on anesthesia, and ether sponges were of- 


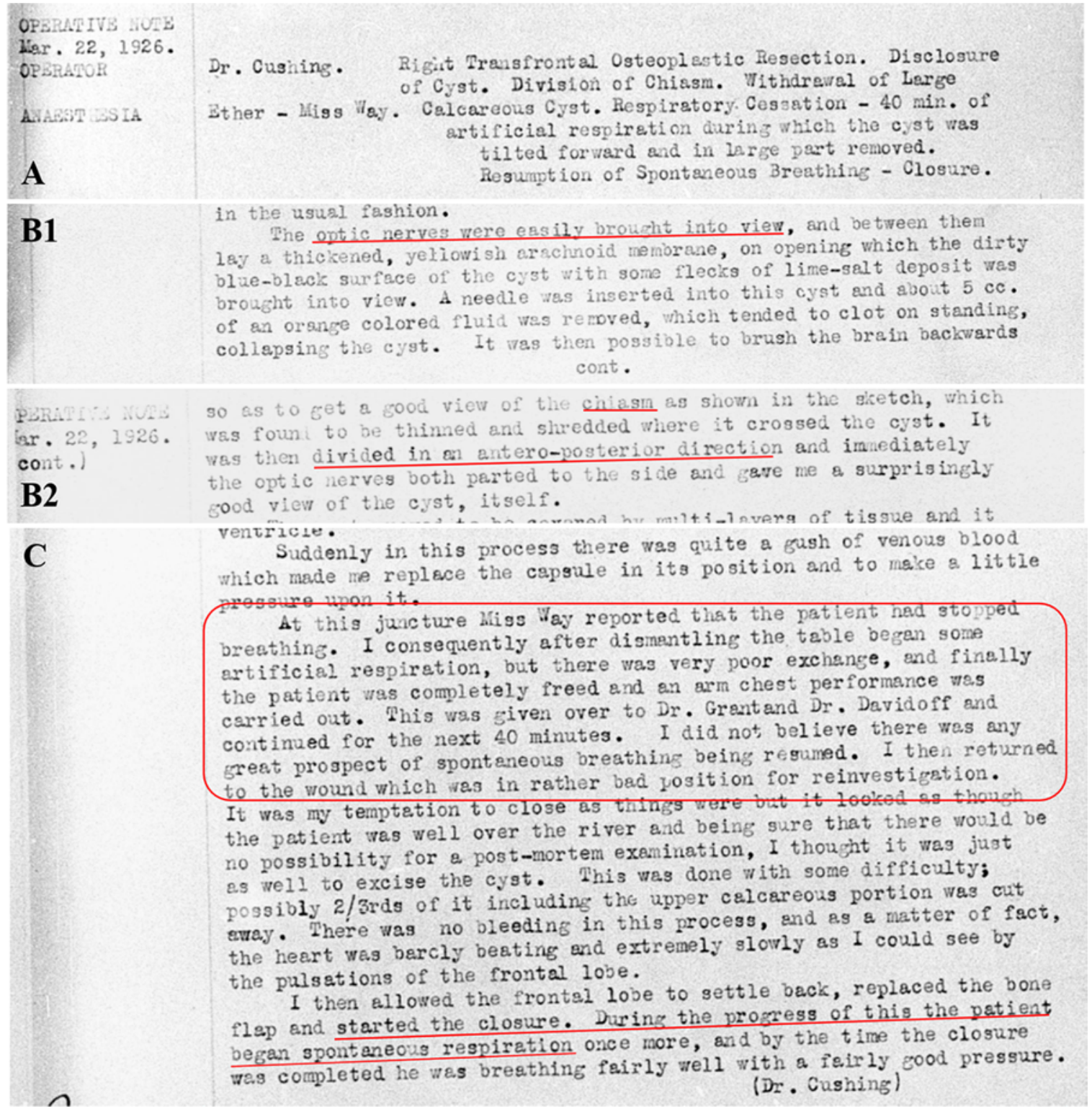

FIG. 4. Description of HW's surgical procedure performed by Cushing on March 22, 1926. A: Short description of the anesthesia (ether inhalation) and operation stating that the tumor was removed during artificial respiration maneuvers. B1 and B2: Cushing's description of the relation found between the optic nerves and the tumor, and how the chiasm was split. C: The red frame marks the description of the moment when the nurse anesthetist (Miss Way) reported that the patient had stopped breathing and what Cushing's reaction was. At the closure phase the patient resumed spontaneous breathing (last underlined line). Courtesy of the Manuscript and Archives Department of the Sterling Memorial Library, Yale University. Public domain. Figure is available in color online only.

ten applied by inexperienced students. ${ }^{5}$ Moreover, when the patient was called for in the operating room, Cushing hurriedly finished his job because the surgeon in charge wanted to leave early for his private practice.

Cushing was stunned when the patient died even before the operation began. He left the hospital and meandered the streets of Boston cursing himself that a human life had been snuffed out due to his ignorance. He was so upset that he seriously considered leaving medical school. ${ }^{39}$ Fortunately, Cushing decided to continue in medicine, but he never forgot this fatal anesthesia incident that be- came a major incentive to dedicate himself more passionately than ever to his work..$^{5,73,40}$ Throughout his remaining 4 years at Harvard, along with his classmate Ernest Amory Codman, he worked out a system of continuously recording pulse, respiration, and temperature during operations with the aim of increasing the safety of surgical procedures., ${ }^{7,1739}$ Cushing added continuous blood pressure records to the ether charts after he brought back a Riva-Rocci sphygmomanometer from his trip to Europe in $1900.6,17,27,41$

A few years later, in 1908 and 1909, Cushing had two 
disheartening experiences that are also noteworthy in his surgical career. ${ }^{33,38}$ Two patients with large supratentorial tumors went into cardiac arrest during the closure stages of their operations. As with HW, Cushing attempted exceptional tactics, in these two cases being posterior fossa decompression and artificial respiration via tracheostomy. ${ }^{33,38}$ These considerable efforts failed to save the patients' lives, but they were not in vain, for they advanced the scientific knowledge of medullary dysfunction.

\section{CP Surgery Prior to HW's Treatment in March 1926}

The beginning of CP surgery can be traced back to Europe in June 1907, at the hands of Sir Victor Horsley and Anton von Eiselsberg. ${ }^{30,44}$ In the exact same month, Horsley succeeded in partially removing a $\mathrm{CP}$ through a subtemporal approach in London, while von Eiselsberg achieved a successful removal using the superior nasal transsphenoidal approach (TSA) in Vienna ${ }^{30,31,44}$ Cushing heard about von Eiselsberg's case at the 1910 American Surgical Association meeting, which was focused on pituitary surgery. In that meeting, Albert Edward Halstead also presented a CP case that he had just operated on through the sublabial TSA with the assistance of Allen Bucker Kanavel in Chicago. ${ }^{20}$ Halstead's case precisely corresponds to the first successful CP operation that was histologically verified. ${ }^{30}$ Cushing modified Kanavel's sublabial TSA, and this would become the standard route he used to approach CPs during the following decade. ${ }^{30,37} \mathrm{Si}-$ multaneously, Oskar Hirsch devised the endonasal TSA for pituitary adenomas and CPs. ${ }^{24,30}$ After that, the major advance in $\mathrm{CP}$ surgery came from Charles Frazier, who in the early 1910s championed the transition from the TSA to the intracranial approach. Specifically, Frazier introduced the subfrontal approach, which soon thereafter would be adopted by Cushing as the primary surgical route for CPs. ${ }^{36}$ Practicing in The Johns Hopkins Hospital, George Heuer would later introduce the pterional approach to CPs. ${ }^{22}$

In 1926, the year that Cushing treated HW, it can be said that CP surgery was fully under development. ${ }^{45}$ At that time, Cushing was the world's most experienced CP surgeon, as he had operated on 81 patients..$^{29,37,45}$ Nevertheless, he had been unable to find almost a third of the tumors during his surgical procedures. ${ }^{37}$ Three of these cases deserve special mention as they profoundly marked Cushing's obsessive search for a successful CP treatment. The most relevant to him was patient MD (surgical case no. 13054), the first intracranial tumor he treated after returning from Sherrington's laboratory, where he had met Alfred Fröhlich. MD was a 16-year-old girl whose tumor was not found in any of the three surgical procedures that Cushing performed on her between February and March 1902. The patient remained comatose until she died, and her brain autopsy revealed a large CP expanding in the suprasellar and third-ventricle compartments. ${ }^{28}$ Cushing deemed it unforgivable to have misdiagnosed this case when he knew that a correct diagnosis had been made in a rather similar case by Fröhlich and satisfactorily operated on by von Eiselsberg. ${ }^{17,28,30,32}$ The other two remarkable cases for Cushing's understanding of CPs were patients DMB (surgical case no. 28747) and WBT (surgical case no. 28818), whose papillary third-ventricle CPs were not found during TSAs in 1911. Meticulous study of their postmortem brain specimens was fundamental for Cushing to change his techniques and philosophy with regard to CPs over the course of his career. ${ }^{29,37}$ The year 1926 marks the beginning of Cushing's last surgical CP period, which was characterized by his discontinuation of the TSA that was predominantly used in his first period (1901-1917), and by his abandonment of the radical tumor removal that characterized the middle period (1919-1925). ${ }^{37}$

\section{Cushing's Awareness of the Vital Role Played by the Hypothalamus: Knowledge Gained Through CP Surgery}

Patient HW was a 17-year-old boy with Fröhlich's syndrome, somnolence, and severe visual loss who was referred to Cushing by a physician in Chicago's Michael Reese Hospital (Fig. 2A). ${ }^{14}$ Radiographs showed sellar calcifications in addition to a curvilinear shadow in the region of the third ventricle that was related to the calcification of the upper cyst wall (Fig. 2B). Cushing's special note on this case, written on March 22, 1926, clearly indicates his fear that surgery might be life threatening (Fig. 3A): "I had about made up my mind to postpone this little boy's case, having had 1-2 disasters from an attempt to remove a calcareous cyst from the situation the X-ray showed the cyst to be in this boy's case...."14

Cushing was almost certainly recalling the disheartening experiences he had had with the aforementioned MD and DA (surgical case no. 235), two patients with CP who died following surgery and whose clinical pictures were very similar to that of $\mathrm{HW} \cdot .^{14} \mathrm{DA}$ was a 14 -year-old girl operated on by Cushing in November 1913 (Fig. 5). He approached DA's tumor through the subfrontal route..$^{10,14} \mathrm{~A}$ large $\mathrm{CP}$ extending from the sellar area to the third ventricle was found but attempts to mobilize the tumor led to extensive hemorrhaging, so Cushing decided to leave it in place and close. Despite the patient developing postoperative hyperthermia and never regaining consciousness, Cushing operated on her again 4 days later and achieved a total removal. Sadly, the patient died the following day. Parts of the circle of Willis and some hypothalamic tissue adhered to the tumor capsule were later found on the tumor specimen (Fig. 5B and C)..$^{10,37}$

Critically analyzing the decisions that he had made in the MD and DA cases allowed Cushing to mentally prepare himself for the challenge of treating HW. Aware of the close relationships between CPs and the vital hypothalamus, he knew with certainty that any forceful, blind manipulation of HW's tumor would invariably injure the hypothalamus, leading to comatose status with uncontrollable hyperthermia and the patient's eventual death. Accordingly, Cushing favored the use of more cautious strategies from the 1920s onward. ${ }^{37}$ These new strategies were fully applied to HW's case, whose lesion was incompletely removed and tumor dissection from the adjacent hypothalamic structures was carefully performed under direct view by splitting the optic chiasm. 


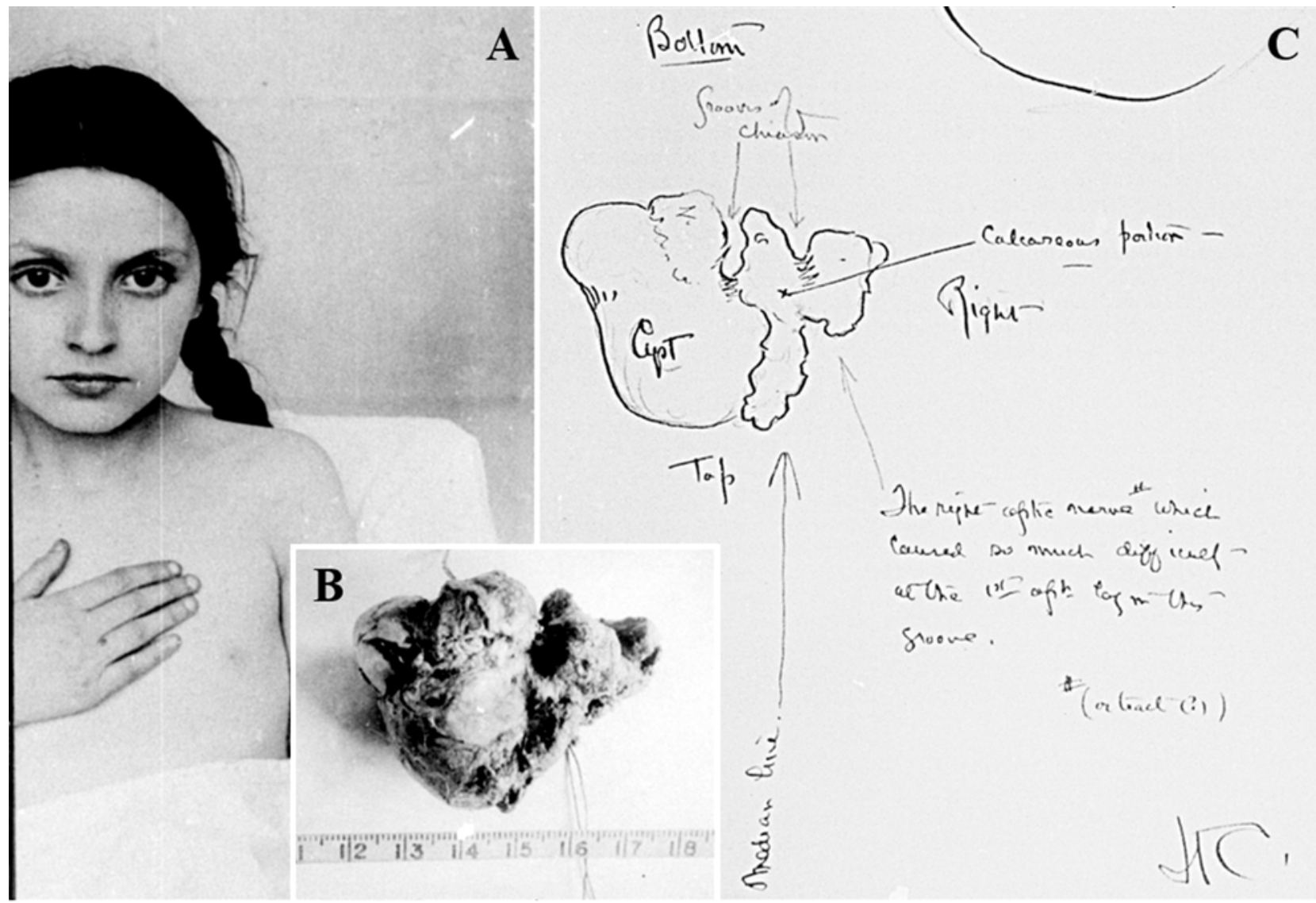

POST OPERATIVE NOTSS

Mov. 17,1913

Dr. Cushing

D
Child left on table for the next 18 hours. The abrupt riso in temperature to $107^{\circ}$ possibly may have been partly due to excessive application of heat. The body was never cold, clammy or sweaty as in cases of shock. Reflexes all began to return soon after transfusion, leaving a particularly rigld, spastic loft side throughout, including jaw, face, arm and leg, with no dorssl flexion or clonus, etc. The richt side much less affected.

The entire picture was almost exactly the same as that in the
case of a child seen in Baltimore with Interpeduncular Tertatoma
who after a cerebellar exploration had become spastic, rigid and
like a spinal animal. The condition lasted for some monthe unt11
the child's death, (atary Donnelly.)

FIG. 5. Patient treated in 1913 with a third-ventricle CP whose removal led to fatal hypothalamic injury. A: Picture of DA (surgical case no. 235) taken in June 1913. She died following radical tumor removal. B: The tumor specimen after en bloc removal presented some hypothalamic tissue adhered to the tumor capsule. C: Sketch of the tumor specimen drawn by Cushing. D: Postoperative note written on November 17, 1913. The red frame indicates Cushing's allusion of the similarity between DA's case and that of MD (Mary D.), a patient treated in 1901. ${ }^{28}$ Courtesy of the Manuscript and Archives Department of the Sterling Memorial Library, Yale University. Public domain. Figure is available in color online only.

\section{The Chiasm-Splitting Procedure: Cushing's First Strategy to Spare the Hypothalamus During CP Surgery}

Cushing's determination to preserve hypothalamic integrity during CP removal led him to develop an innovative and valuable technique consisting of transecting the chiasm in an anteroposterior direction. This strategy would widen the access to the retrochiasmatic-hypothalamic area and counteract the lack of proper illumination. Nevertheless, Cushing was reluctant to proceed with such a surgical innovation as it would invariably lead to an irreversible vision impairment. The decision to finally split HW's chiasm was the end result of a careful reflection over 
several years, as indicated in his special note written on March 22, 1926 (Fig. 3A): ${ }^{14}$

\begin{abstract}
...I had long planned to do, namely, to divide the chiasm in an anteroposterior direction, thereby committing the boy to a bitemporal hemianopsia even should I be able to spare the nerves otherwise. I thought this would give better access to the tumor but I had little idea how much the procedure would simplify these operations until I came to try it. Heretofore we have been struggling with an attempt to dislodge a growth which has been imprisoned by the chiasmal cross-tree. Consequently, I have had always to work in between the two legs of the chiasm and have been very fearful of damaging the nerves.
\end{abstract}

According to the BTR, Cushing first envisioned chiasm splitting as a potential solution to reach retrochiasmatic CPs and to minimize hypothalamic damage in 1919, with patient LW (surgical case no. 10067). LW was a 15-year-old girl with infantilism, visual loss, and memory disturbances, who had a good outcome following several brain surgeries.,14 After the third surgery performed on her on May 8, 1919, through a subfrontal route, Cushing wrote (Fig. 6): ${ }^{14}$

It is quite probable and indeed certain that, had the chiasm been split antero-posteriorly, it might have been possible to remove the tumor in its totality. I am under the impression that in the future it might be best to deliberately do this and leave the patient with a permanent bitemporal hemianopsia but with a greater certainty that there would be no recurrence of trouble.

A few years later, coinciding with the treatment of AM (surgical case no. 20814) in 1924, Cushing again mulled over chiasm splitting as a plausible surgical strategy. AM was a 20-year-old woman with Fröhlich's syndrome, somnolence, and psychiatric disturbances, whose first surgical attempt through a subfrontal approach on March 15, 1924, failed to reach the tumor. Cushing knew with certainty that the tumor was hidden in the third ventricle, behind the chiasm, and wrote: ${ }^{14,34}$

The only thing that could have been done in the way of improving the field of operation in this case would have been to split the chiasm in an antero-posterior direction. This would have inflicted the patient with a permanent bitemporal hemianopsia, and I did not quite have the courage to carry out this measure, though I should have done so I think in another case, and will be inclined to do this on the next occasion provided there is a pre-existent bitemporal field defect.

The opportunity to carry out the splitting strategy eventually came with HW, whose vision was already severely impaired (blind left eye and right temporal hemianopsia). Cushing found chiasm splitting a very useful technique to expose the circumferential attachment plane between the tumor's central part and the adjacent third-ventricle floor. HW's record includes a sketch of this important surgical maneuver (Fig. 3B), which was described by Cushing as follows (Fig. 4B1 and B2): $:^{14}$

The optic nerves were easily brought into view, and between them lay a thickened, yellowish arachnoid membrane, on opening which the dirty blue-black surface of the cyst with some flecks of lime-salt deposit was brought into view. A needle was inserted into this cyst and about $5 \mathrm{cc}$. of an orange colored fluid was removed, which tended to clot on standing, collapsing the cyst. It was then possible to brush the brain backwards so as to get a good view of the chiasm as shown in the sketch, which was found to be thinned and shredded where it crossed the cyst. It was then divided in an antero-posterior direction and immediately the optic nerves both parted to the side and gave me a surprisingly good view of the cyst, itself.

\section{Cushing's Determined Response to HW's Intraoperative Cardiac Arrest}

During surgical dissection, when the tumor was being dislodged from the third-ventricle cavity, HW, who had been anesthetized by ether inhalation (without endotracheal intubation), ${ }^{5,14}$ unexpectedly stopped breathing. Aware of possible hypothalamic impairment, Cushing knew HW's chances of survival were rather slim. Nevertheless, he did not "throw in the towel," and he fought to the end to save HW's life. Cushing initially administered artificial respiration himself; then he calmly resumed tumor excision while his assistants Drs. Francis C. Grant and Leo M. Davidoff performed 40 minutes of cardiopulmonary resuscitation maneuvers. ${ }^{14}$ In Cushing's own words (Fig. 4C): ${ }^{14}$

The cyst proved to be covered by multi-layers of tissue and it was a little difficult to know just where to begin the dissection. However, I finally succeeded in getting in below the layer of what I take to be dural capsule and began gradually to brush the cyst, which I should think in its distended form was about the size of a pigeon's egg or larger.... There was little bleeding on one occasion, which was easily controlled.... Finally the growth began to dislodge and the hard egg-shelled portion of the cyst began to lift out from the cavity in the third ventricle. Suddenly in this process there was quite a gush of venous blood which made me replace the capsule in its position and to make a little pressure upon it. At this juncture Miss Way reported that the patient had stopped breathing. I consequently after dismantling the table began some artificial respiration, but there was very poor exchange, and finally the patient was completely freed and an arm chest performance was carried out. This was given over to Dr. Grant and Dr. Davidoff and continued for the next 40 minutes.

Based on our review of the Cushing BTR, three other patients with $\mathrm{CP}$ were given artificial respiration during surgery (surgical case nos. 14996, 26200, and 28383). ${ }^{14}$ Nevertheless, unlike HW, whose tumor was removed during ongoing cardiopulmonary resuscitation, in the other cases either surgery was concluded without tumor removal or the tumor was removed after spontaneous respiration had resumed. Cushing described the stage of HW's tumor removal as follows (Fig. 4C): "I then returned to the wound which was in rather bad position for reinvestigation. It was my temptation to close as things were...but...I thought...to excise the cyst. This was done with some difficulty; possibly $2 / 3$ rds of it including the upper calcareous portion was cut away."14

Cushing's effort was vindicated, as HW recovered spontaneous respiration during the closure phase. At the end of the surgical procedure HW was breathing well and his blood pressure was also good. He was later discharged in good condition, remaining so for at least 3 years following surgery. ${ }^{14,29,37}$

\section{Difficult Decisions in Desperate Surgical Situations: Ethical Considerations and Lessons to Be Drawn From Cushing's Experiences}

Foreseeing patient outcome and making rapid deci- 

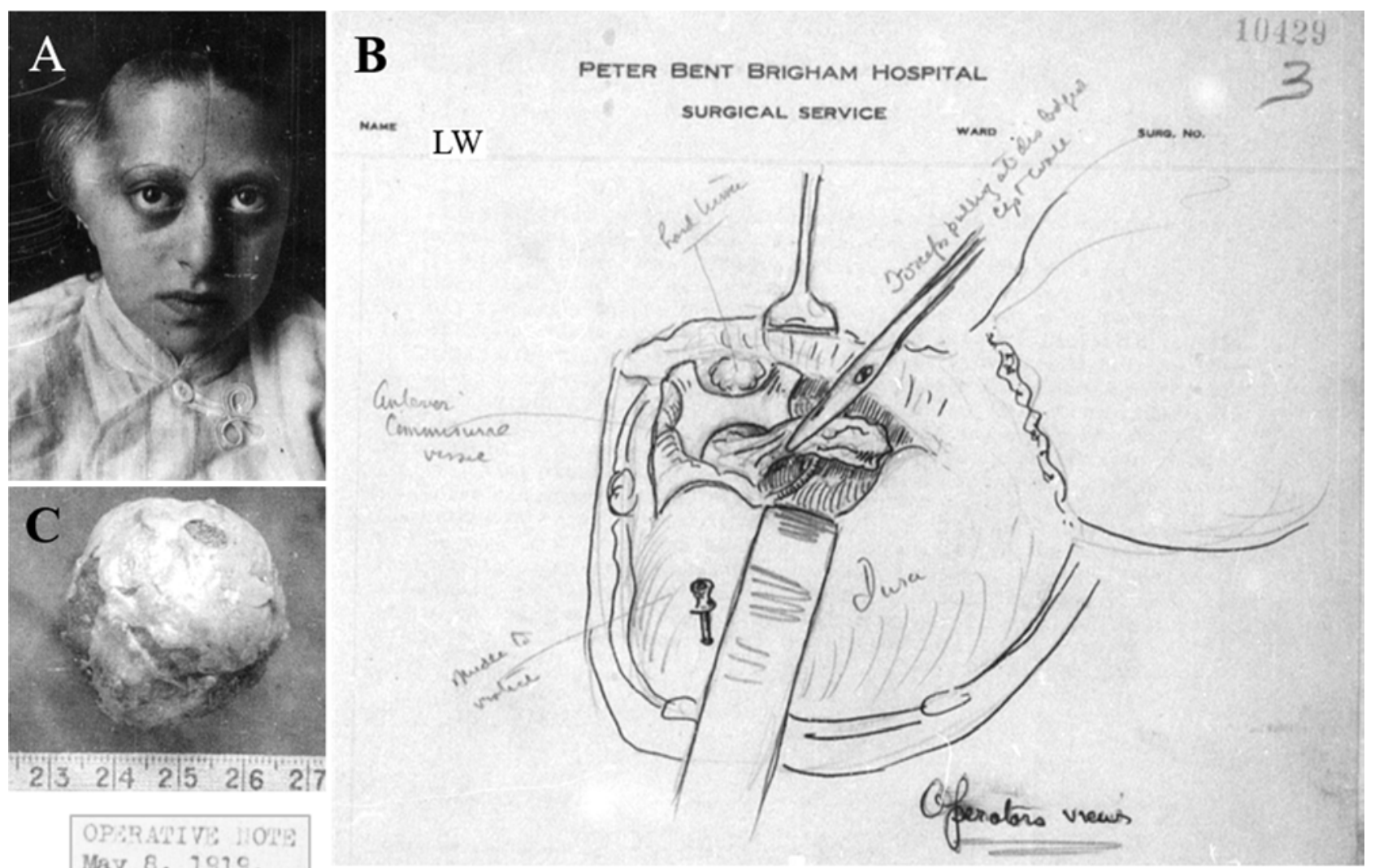

\section{D} OPZRATIVE HOME May 8, 1919. ara tooking between it and Dirlng all this procedure the child's condition amarently was unaltertumor, which could bleeding apneared to have been done. The hard zodular left in sitia, thouch la bated between the anterior legs of the chiasm, was tumor could be dislodged. It is quite probable and indeed certain that, had the chiasm been spilt antero-posterlor $2 y$, it might have boen possibie to remove the tumor in 1 ts totality. I am under the impression that in the future it might be best to deliberately do this and leave the patient there would case that, even thoweh some frament of the cyst wall may have been le ft, it may be many yoars before a complete now cyst will form, at 2,east of sufficient size to occlude the ventricular outlets.

$$
\text { (Dr. Cushing.) }
$$

FIG. 6. Cushing's first reflection in the BTR about the possibility of chiasm splitting. A: Picture of LW (surgical case no. 10067) taken on April 28, 1919. B: Sketch showing the surgeon's view through a subfrontal approach. C: Tumor specimen after en bloc removal. D: Operative note written by Cushing on May 8, 1919. The red frame highlights Cushing's first explicit mention in the BTR about the possibility of splitting the chiasm anteroposteriorly. Courtesy of the Manuscript and Archives Department of the Sterling Memorial Library, Yale University. Public domain. Figure is available in color online only.

sions when dealing with unexpected complications during a surgical procedure are issues inextricably linked to the practice of neurosurgery. The way Cushing coped with the serious difficulties posed by HW's case is instructive to underscore the dilemma neurosurgeons face when making life-and-death decisions. Cushing's determination to use the chiasm-splitting technique and then calmly proceed with tumor removal while his assistants were performing resuscitation maneuvers goes beyond his resolve to save his patient's life. It also reflects his tough character and proactive attitude to fight to the end, in this case overcoming the technical obstacles and limited CP knowledge at that time. Certainly, Cushing's success in an apparently hopeless case illustrates that a physician's decisions are crucial to a patient's ultimate outcome, despite the individual human factor being largely dismissed 
by the current paradigm of modern evidence-based medicine.

As Cushing himself acknowledged, an additional reason he continued HW's surgery was to understand the tumor-brain relationships (Fig. 4C). Reasonable ethical doubts regarding this case might arise nowadays, as acquisition of medical knowledge currently requires strict adherence to prior informed consent ${ }^{42}$ Nonetheless, Cushing's decisions should be considered in their historical context; HW was treated when fewer than a dozen surgeons worldwide were operating on CPs, and most CP surgeries were doomed to fail. ${ }^{30,45}$ Ethics were paramount for Cushing. He tried to put himself in his patients' shoes with the aim of envisaging the impact of his actions on both their physical and mental quality of life. In fact, it was his professional honesty that encouraged him to investigate the reasons why any surgery had failed. ${ }^{1,11,12,15,18,35}$ In essence, Cushing's concepts and perspectives about the importance of scientific knowledge and ethical commitment to the patients for proper decision-making are as relevant as ever to guide current generations of neurosurgeons. ${ }^{1,11}$

\section{Conclusions}

Harvey Cushing is a true model of strict professionalism and ethics for patient care. Analysis of the decisions that he made in the HW case provides valuable lessons for neurosurgeons today, particularly the importance of dedicating all possible time and energy to save a life.

\section{Acknowledgments}

We wish to especially thank Bill Landis and all the staff of the Manuscript and Archives Department of the Sterling Memorial Library, Yale University (New Haven, Connecticut), for their kind assistance in accessing the Cushing Brain Tumor Registry. We are also grateful to Melissa Grafe, John R. Bumstead Librarian for Medical History, Head of the Medical Historical Library of the Cushing/Whitney Medical Library, Yale University, for her kind assistance during our visit to that library and for arranging permission to reproduce Cushing's picture from the Harvey Cushing Photograph Digitalized Collection. We are indebted to Liliya Gusakova and Crystal Smith, Reference Librarians in the National Library of Medicine, NIH (Bethesda, Maryland), and Jack Eckert and the staff of the Francis Countway Medical Library at Harvard Medical School (Boston, Massachusetts), for their kind assistance during the process of searching for and retrieving some of the original research material used in this study. Finally, we thank Bostonian George Hamilton for his critical review of the language and style of the paper.

\section{References}

1. Al-Mefty O, Laws ER, Popp AJ: Surgical neurology: Harvey Cushing's endangered legacy. J Neurosurg [epub ahead of print May 3, 2019. DOI: 10.3171/2019.1.JNS182290]

2. Bailey P: Harvey Williams Cushing, M.D. obituary. Arch Neurol Psychiatry 42:1140-1144, 1939

3. Bailey P: Pepper pot, in Bucy PC (ed): Neurosurgical Giants: Feet of Clay and Iron. New York: Elsevier, 1985, pp 73-89

4. Bailey P: Up From Little Egypt. Chicago: Buckskin Press, 1969

5. Bingham WF: The early history of neurosurgical anesthesia. J Neurosurg 39:568-584, 1973

6. Black PM: Harvey Cushing at the Peter Bent Brigham Hospital. Neurosurgery 45:990-1001, 1999
7. Bliss M: Harvey Cushing: A Life in Surgery. New York: Oxford University Press, 2005

8. Carey ME: Major Harvey Cushing's difficulties with the British and American armies during World War I. J Neurosurg 121:319-327, 2014

9. Cohen-Gadol AA, Spencer DD: The Legacy of Harvey Cushing: Profiles of Patient Care. New York: Thieme, 2007

10. Cushing H: Intracranial Tumors: Notes Upon a Series of Two Thousand Verified Cases With Surgical-Mortality Percentages Pertaining Thereto. Springfield, IL: Charles C. Thomas, 1932, pp 93-98

11. Cushing H: The special field of neurological surgery. Bull Johns Hopkins Hosp 16:77-87, 1905

12. Cushing H: The special field of neurological surgery after another interval. Arch Neurol Psychiatry 4:603-637, 1920

13. Cushing H: The special field of neurological surgery: five years later. Bull Johns Hopkins Hosp 21:325-339, 1910

14. Cushing HW: Harvey Williams Cushing Papers in the Yale University Library (MS 160). Brain Tumor Registry, Series I, Boxes 89-107. Yale University Library (http:// archives.yale.edu/repositories/12/resources/4462) [Accessed December 2, 2019]

15. Cutler EC: Harvey (Williams) Cushing. Science 90:475-482, 1939

16. Feindel W: Osler and the "medico-chirurgical neurologists": Horsley, Cushing, and Penfield. J Neurosurg 99:188-199, 2003

17. Fulton JF: Harvey Cushing: A Biography. Springfield, IL: Charles C. Thomas, 1946

18. Greenblatt SH: Harvey Cushing's paradigmatic contribution to neurosurgery and the evolution of his thoughts about specialization. Bull Hist Med 77:789-822, 2003

19. Greenblatt SH, Smith DC: The emergence of Cushing's leadership: 1901 to 1920, in Greenblatt SH, Forcht Dagi T, Epstein MH (eds): A History of Neurosurgery: In Its Scientific and Professional Context. Park Ridge, IL: American Association of Neurological Surgeons, 1997, pp 167-190

20. Halstead AE: Remarks on the operative treatment of tumors of the hypophysis: with the report of two cases operated on by an oro-nasal method. Surg Gynecol Obstet 10:494-502, 1910

21. Harvey Cushing Society: A Bibliography of the Writings of Harvey Cushing: Prepared on the Occasion of His Seventieth Birthday, April 8, 1939. Springfield, IL: Charles C. Thomas, 1939

22. Heuer GJ: Surgical experiences with an intracranial approach to chiasmal lesions. Arch Surg 1:368-381, 1920

23. Heyl L: A selection of Harvey Cushing anecdotes. J Neurosurg 30:365-376, 1969

24. Hirsch O, Hamlin H: Symptomatology and treatment of the hypophyseal duct tumors (craniopharyngiomas). Confin Neurol 19:153-219, 1959

25. Jefferson G: Harvey Cushing (1869-1939), in Bucy PC (ed): Neurosurgical Giants: Feet of Clay and Iron. New York: Elsevier, 1985, pp 51-67

26. Long DM: Harvey Cushing at Johns Hopkins. Neurosurgery 45:983-989, 1999

27. Moore FD: Harvey Cushing. General surgeon, biologist, professor. J Neurosurg 31:262-270, 1969

28. Pascual JM, Prieto R: Harvey Cushing and pituitary Case Number 3 (Mary D.): the origin of this most baffling problem in neurosurgery. Neurosurg Focus 41(1):E6, 2016

29. Pascual JM, Prieto R, Barrios L: Harvey Cushing's craniopharyngioma treatment: Part 1. Identification and clinicopathological characterization of this challenging pituitary tumor. J Neurosurg 131:949-963, 2018

30. Pascual JM, Prieto R, Castro-Dufourny I, Carrasco R, Strauss S, Barrios L: Development of intracranial approaches 
for craniopharyngiomas: an analysis of the first 160 historical procedures. Neurosurg Focus 36(4):E13, 2014

31. Pascual JM, Prieto R, Mazzarello P: Sir Victor Horsley: pioneer craniopharyngioma surgeon. J Neurosurg 123:39-51, 2015

32. Pascual JM, Prieto R, Rosdolsky M, Strauss S, CastroDufourny I, Hofecker V, et al: Cystic tumors of the pituitary infundibulum: seminal autopsy specimens (1899 to 1904) that allowed clinical-pathological craniopharyngioma characterization. Pituitary 21:393-405, 2018

33. Pendleton C, Jiang B, Geocadin RG, Quinones-Hinojosa A: "Any possible restoration of function could not occur": Harvey Cushing and the early description of brain death. World Neurosurg 77:394-397, 2012

34. Prieto R, Pascual JM: Norman M. Dott, master of hypothalamic craniopharyngioma surgery: the decisive mentoring of Harvey Cushing and Percival Bailey at Peter Bent Brigham Hospital. J Neurosurg 127:927-940, 2017

35. Prieto R, Pascual JM: Percival S. Bailey: eminent scholar of neurosciences who revealed the workings of the hypothalamus through clinicopathological research on craniopharyngiomas. J Neurosurg [epub ahead of print June 14, 2019. DOI: 10.3171/2019.3.JNS183145]

36. Prieto R, Pascual JM, Barrios L: Charles H. Frazier's craniopharyngioma treatment: pivotal role of the transfrontal approach. J Neurosurg [epub ahead of print November 8, 2019. DOI: 10.3171/2019.8.JNS191508]

37. Prieto R, Pascual JM, Barrios L: Harvey Cushing's craniopharyngioma treatment: Part 2. Surgical strategies and results of his pioneering series. J Neurosurg 131:964-978, 2018

38. Shelton BA, O'Hara E, Tubbs RS, Shoja MM, Barker FG II, Cohen-Gadol AA: Emergency suboccipital decompression for respiratory arrest during supratentorial surgery: the untold story of a surgeon's courage in times of despair. J Neurosurg 110:391-394, 2009

39. Thomson EH: Harvey Cushing. Surgeon, Author, Artist. New York: Henry Schuman, 1950
40. Tilney NL: Harvey Cushing and the evolution of a polymath. Surg Gynecol Obstet 162:285-290, 1986

41. Tilney NL: Harvey Cushing and the surgical research laboratory. Surg Gynecol Obstet 151:263-270, 1980

42. Umansky F, Black PL, DiRocco C, Ferrer E, Goel A, Malik GM, et al: Statement of Ethics in Neurosurgery of the World Federation of Neurosurgical Societies. World Neurosurg 76:239-247, 2011

43. Viets HR: Harvey Cushing: an anecdotal biography. Mass Hist Soc Proc 81:194-207, 1969

44. von Eiselsberg F: My experience about operations upon the hypophysis. Trans Am Surg Assoc 28:55-72, 1910

45. Walker AE (ed): A History of Neurological Surgery. New York: The Williams \& Wilkins Company, 1951

\section{Disclosures}

The authors report no conflict of interest concerning the materials or methods used in this study or the findings specified in this paper.

\section{Author Contributions}

Conception and design: both authors. Acquisition of data: both authors. Analysis and interpretation of data: both authors. Drafting the article: Prieto. Critically revising the article: both authors. Reviewed submitted version of manuscript: both authors. Approved the final version of the manuscript on behalf of both authors: Prieto.

\section{Correspondence}

Ruth Prieto: Puerta de Hierro University Hospital, Madrid, Spain. rprieto29@hotmail.com. 